Article

\title{
Controversial Connections: The Water-Energy-Food Nexus in the Blue Nile Basin of Ethiopia
}

\author{
Detlef Müller-Mahn *(D) and Million Gebreyes $(\mathbb{D}$ \\ Department of Geography, University of Bonn, D-53115 Bonn, Germany \\ * Correspondence: mueller-mahn@uni-bonn.de
}

Received: 29 July 2019; Accepted: 29 August 2019; Published: 5 September 2019

check for updates

\begin{abstract}
The article takes hydro-development schemes in the Upper Blue Nile Basin of Ethiopia as an example to discuss the suitability and shortcomings of nexus approaches for the analysis of complex socio-ecological transformations. Based on critical theoretical debates and extensive field research in Ethiopia, the paper broadens the nexus perspective by integrating the three analytical dimensions of time, space, and power. The empirical material comes from a case study of the Fincha-Amerti-Neshe scheme that was implemented in three consecutive stages over almost half a century, combining dams, hydro-power plants, large-scale sugar cane plantations, and a factory for sugar production. The empirical findings follow the historical stages of the scheme and their physical outcomes, which affected much more than just water, energy, and food. The paper explores socio-ecological transformations along the analytical dimensions of time, scale, and power. First, it views time and temporality as essential aspects of change and calls for a more systematic recognition of the historical context out of which development trajectories and current nexus situations have emerged. Second, it takes a cross-scalar perspective to explain how local land use is influenced by regional and global drivers. And third, it emphasizes the importance of asymmetric power structures to explain the dynamics of hydro-developments and their social consequences. In conclusion, the paper calls for a "nexus-plus" perspective that is more sensitive to the historical and cross-scalar embeddedness of hydro-development, and which enables more inclusive and fair governance of scarce resources.
\end{abstract}

Keywords: water-energy-food; nexus-plus; Ethiopia; Fincha-Amerti-Neshe scheme; time; scale; power

\section{Introduction}

The water-energy-food (W-E-F) nexus approach was introduced into the politics and practice of development about a decade ago, with the intention of managing water use more efficiently [1]. Today, this approach is widely accepted in development practice, whereas it is controversially debated in development studies. Some researchers contend that the W-E-F nexus is incomplete or immature and needs to be further improved [2] (p.610) while other critical voices argue that it is misleading and should therefore be abandoned [3,4]. This paper explores the usefulness and deficiencies of the approach, with reference to a case study from Ethiopia. This country provides ample material for a nexus study and illustrates the significance of the issue, because the construction of dams plays a crucial role in its national development strategy.

The Ethiopian highlands have long been considered the water towers of the Horn of Africa and the Nile basin. With recent hydro-developments, the mountain areas have gained an additional new function as power houses and engines of economic growth in the country. This places the connection between water, energy, and food at center stage, because water is increasingly becoming an object of competing demands and conflicts. Some of the new hydro-development schemes are spectacular 
mega-projects like the Grand Renaissance Dam on the Blue Nile, but medium-scale projects like the one presented here are also impressive contributions to national development. The map (Figure 1) shows the location of the major dam sites and sugar factories. Each of the factories is surrounded by huge sugar cane plantations of several ten thousand hectares, as shown in the enlarged inlay map of the Fincha-Amerti-Neshe scheme.

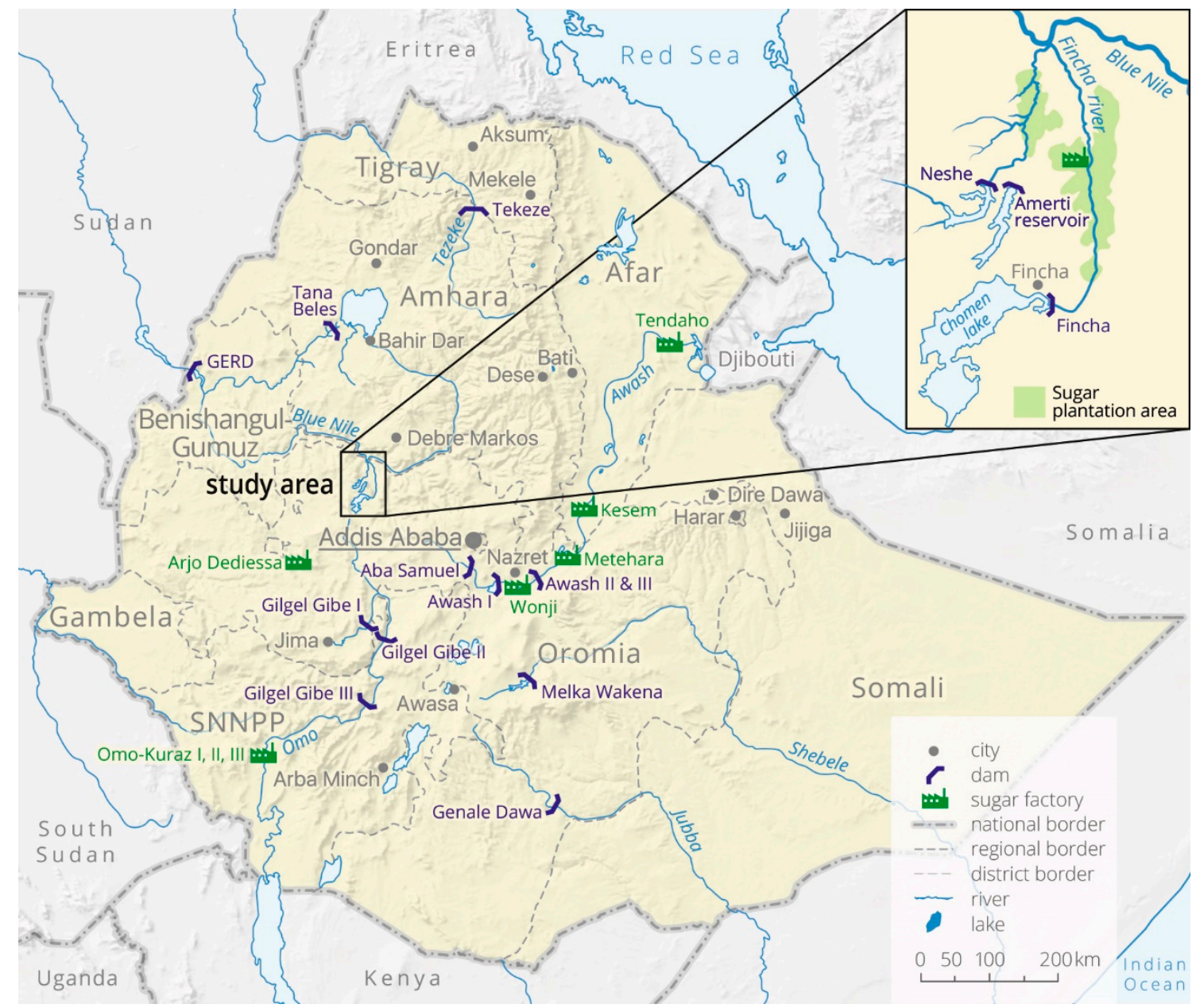

Figure 1. Major dam sites and location of the study area in Ethiopia.

The government is making great efforts to utilize the available hydraulic resources for energy production and the expansion of irrigated agriculture. However, this puts the country's ambitious modernization and infrastructure program in a dilemma, because it requires decisions over priorities, i.e., how to reconcile urban and rural development, energy provision, and food supply. Energy production is the backbone of the government's growth and industrialization strategy. At the same time, the rising food demand of a growing population of already more than 100 million requires the expansion of irrigated agriculture. Against this backdrop it is obvious that the nexus perspective is highly relevant in respect of Ethiopia's ongoing hydro-development program, as several studies have already shown $[5,6]$. Even so, some questions remain open and deserve further attention:

- Which other factors besides water, energy, and food play a role in the ongoing socio-ecological transformation, and how can they be integrated in a nexus perspective?

- How can politics and power behind the W-E-F nexus be unveiled?

- In which way does the path-dependency of development influence the W-E-F nexus?

After this introduction, the paper continues with a brief review of nexus debates, their conceptual background, and the controversies over the merits and shortcomings of the approach. The third chapter 
describes the underlying empirical study and its methods. Chapter four highlights the main findings of the study, which are then discussed in chapter five with regard to a broadening of perspectives towards a nexus-plus approach.

\section{Nexus Approaches: Conceptual Background and Controversial Debates}

The W-E-F nexus approach was officially launched at the World Economic Forum in 2011. The reason why the topic was raised at such a prominent meeting of influential world leaders lies in its political importance. Scientists had warned that water was becoming a global security issue, requiring urgent action to avert a global economic and geopolitical crisis [7]. The high-level meeting helped to promote the concept by drawing the attention of international business and politicians to the management of scarce water resources. Aiming at a better understanding of the interconnectedness between water, energy, and food, the main intention of the nexus approach is the improvement of resource use efficiency at the interface between the three sectors, with water being pivotal in the triangular relationship [1].

The relevance of the nexus approach is obvious, as it responds to increasing scarcity and competition between different demands at regional and national scales, especially in the developing world. Nexus thinking seeks to embrace complexity and develop a holistic understanding of the mutual interactions, cross-sectoral influences, and relationships within socio-ecological systems [8]. As a pragmatic and policy-oriented approach, it seeks to contribute to the solution of global problems, including the Agenda 2030 and the Sustainable Development Goals [9]. In the same pragmatic vein, nexus thinking calls for better coordination of scientific research and development practice, and integration of existing approaches such as the Integrated Water Resources Management framework [7].

When the nexus approach was presented at the World Economic Forum as a new conceptual framework for water resources management, it was not explicitly mentioned that its origins are quite a bit older, and that its key idea is neither unique nor particularly sophisticated. It is evident that nexus thinking follows the tradition of other schools of thought circling around connectedness, mutual relationships, and interaction in the regional context of water use. There is, for example, the school of landscape ecology that was established in the mid-20th century. It later became influential in the study of complex relationships between ecological processes in physical landscapes. Landscape ecology still has its place in physical geography, despite its rather vague definition of landscapes as research objects [10]. Other intellectual forerunners of nexus thinking come from the huge body of ecosystem studies. With the pioneering works of Holling [11], a whole set of questions gained importance from the early 1970s concerning such issues as environmental stability and change, disturbance and resilience, and sustainability transitions. After alarming reports like the Club of Rome's "Limits to Growth" [12], or the Brundtland report "Our common future" [13], the world became increasingly aware of the existential importance of global environmental change and sustainability. With the growing concern in respect of climate change and its impact from the 1990s, scientists also had to acknowledge the social dimension of the problem. As a consequence, research began to address the coupling mechanisms between social and environmental processes of change, including issues like environmental governance, adaptation to climate change, the problem of planetary boundaries, resilience, and pathways to sustainable futures [14]. Critical authors with a background in political economy viewed the global environmental crisis as a result of changing societal relations with nature under the influence of neoliberalism and global capitalism [15]. They were able to show that phenomena like natural hazards or resource scarcity do not have their origins in nature, but need to be explained and politically addressed in relation to their societal causes [16,17]. From a political ecology perspective, the critical issues of water use, scarcity, and resource management cannot be reduced to a technical dimension, but require an understanding of the social causes of scarcity [18].

Today, the nexus approach is widely applied as a planning and management tool, especially under conditions of resource scarcity. In scientific debates, however, its analytical qualities and conceptual foundations are controversially debated. The critique focuses on two main points [19]. The first is 
whether the specific connections highlighted by the nexus of water, energy, and food are able to capture the complexity of water-related system changes. This raises the question of which other important aspects are missing, and what exactly should be included in a nexus analysis. The second critical point is more fundamental. It is that the nexus concept is misleading, because it masks the underlying causes of unsustainable development, poverty, and resource degradation.

The first point of critique addresses the incompleteness of the nexus focus and its limitation to the triangle of water-energy-food. Obviously, the selection of just three nodes may appear arbitrary, and this critique is enhanced by the heterogeneity of the three categories: water is an input in hydro-development schemes, food is an output, and energy may be both an input and an output [3]. Highlighting these three nodes means that many other potentially important nodes are excluded, such as land, climate, population, infrastructure etc., resulting in a misleading simplification [3,20]. In the literature, land often plays a central role, either as a resource for food production or as a source of eco-system services, such as hydrological flows [20]. It has therefore been suggested that land should be included in the nexus perspective, as, for example, in the Integrated Climate Land Water Energy assessment approach [21,22]. The focus on land has so far mainly referred to land-use change, i.e., from food to energy production or vice versa, or it is part of macro-economic modelling approaches; but what deserves more attention in the broadening of nexus-perspectives are micro-level phenomena like property rights and socio-economic dynamics within local communities that are caused by land acquisition, investment, and capital flows $[20,23]$. These additional nodes can easily be incorporated into a nexus-plus perspective.

The second and more fundamental point of critique focuses on the failure of the conventional W-E-F nexus perspective to address questions of power, politics, governance, socio-economic conditions, and equity. The reason why the nexus remains completely a-political becomes obvious if we look at the role international business played in its design [4]. The initial impulse for the approach came from the 2030 Water Resource Group, which was founded in 2008 under the auspices of the World Bank. The group consisted of global players from the food and beverage industry, such as the Barilla Group, Coca-Cola, Nestle, SABMiller, PepsiCo, New Holland Agriculture, Standard Chartered Bank, and Syngenta. Other partners include the World Wildlife Fund for Nature (WWF), the Global Green Growth Institute, the World Economic Forum (WEF), and The Global Water Partnership. The group receives funding from multilateral development banks such as the World Bank, International Finance Corporation (IFC), and the Inter-American Development Bank, and official development agencies such as the Swiss Agency for Development and Cooperation, the Swedish International Development Cooperation Agency ISIDA, and the United States Agency for International Development (USAID). Driven by the combined interests of international development and business, the nexus approach is firmly embedded in the logics of neoliberalism, and follows a primarily technical logic. Its aim is the technical management of scarcity, not an alleviation of the social and political causes of scarcity [4]. It serves the economy, but leaves out questions of social well-being, fairness, and justice.

Leck et al. [24] argue that the private sector has supported nexus thinking in order to ensure a supply of critical resources such as water, but also to secure the generation of revenue through public-private partnerships in water-related investment programs. Thus, it remains questionable as to whether these initiatives lead to a meaningful socio-ecological transformation, or simply to a "green washing" of development cooperation projects. In view of the deep entanglement of the nexus approach in neoliberal logics, some critical authors argue that it is not worth the attention it is currently getting in development research and practice [3], and that "the information excluded from studies claiming to implement a nexus approach might be of greater importance to science and policy than the information included in the analysis" [3] (p. 113). The incompleteness of the nexus approach is obvious, since the selection of just three sectors does indeed appear to be arbitrary. As Allouche et al. [25] (p. 622) put it, "The nexus as a concept must more fully embrace inclusiveness, so that the interrelationships it represents-including planetary boundaries and the manifestation at the local level—can reflect local realities and human needs". 
In the following case study of a hydro-development scheme in Ethiopia we will adopt a historical perspective to explore how the project emerged through different stages of development, and how these stages were characterized by a specific embeddedness of local development in the national and global contexts.

\section{Materials and Methods}

The study presented in this paper was part of a larger interdisciplinary project called Nile-nexus, which was financed by the Belmont Forum and the German Research Foundation (DFG) from 2016 to 2019. The project's objective was to analyze the emerging food-energy-water pressures in the rapidly changing ecosystem of the Blue Nile Mountains, and to identify options for a more sustainable management of the nexus. The study was conducted in three blocks of qualitative field work each lasting two to four weeks between March 2017 and January 2018, using mainly key informant interviews and focus group discussions. The step-wise organization made it possible to increasingly refine the questions and improve local contacts, despite a rather difficult research environment. Field work was carried out by the authors and a female Ethiopian research assistant who is currently preparing her $\mathrm{PhD}$ thesis at Addis Ababa University, and who speaks the local language Oromifa. Being of Oromo origin herself, the research assistant had relatively easy access to the local population.

The field work was aimed at understanding how local communities were affected by project activities, and what happened to those people who were resettled due to hydro-development activities. As usual, the collection and interpretation of oral history became more complicated with growing historical distance to the events that had to be retrieved from people's memories. Another complication was finding people who had been displaced by development. Finding the population that had been resettled by the earlier dam projects of Fincha and Amerti required a search mission, but in the end it was possible to identify and interview 30 people who had been displaced several decades before. In addition, six focus group discussions were carried out with community members, and 10 expert interviews with district and zonal officials, sugar factory experts and dam operators. Additional data for the study came from secondary sources, including policy papers, project documents, annual plans, and official reports from various national and regional authorities, including the Federal Ministry of Water, the Regional Bureau of Water, the Abay Basin Authority, the Horo-Gudru Welega Zone Finance and Economic Office, and the Abay Chomen District Office. Data analysis was assisted by MAXQDA qualitative data analysis software.

The Fincha-Amerti-Neshe scheme consists of a number of dams, underground tunnels, power stations and roads, together with large-scale irrigation infrastructure, new settlements and agro-industries, which were constructed in three consecutive stages over a period of almost half a century. The main dam on Fincha River was completed in 1973, with an additional storage dam built on Amerti River in 1987, and another smaller reservoir on Neshe River in 2012 (Figure 1 and Figure 5). Together these infrastructures constitute a complex hydro-development project that completely transformed the regional landscape and had far-reaching consequences for the livelihoods of the local population. The scheme is located in the central Ethiopian highlands about $200 \mathrm{~km}$ northwest of Addis Ababa on one of the tributaries of the Blue Nile. The area belongs to the Abay Chomen District of Oromia Regional State. The total population of the district grew from 48,316 in 2007 to 64,672 in 2017 [26,27].

The complex hydro-development scheme is skillfully placed in a landscape that is characterized by high altitudinal differences and a steep slope between the highland areas and the deeply incised valley of the Blue Nile. The setting can be seen on a series of satellite images that document the different stages of implementation of the dam project. They show the highland area in the lower left corner, the Blue Nile in the upper right corner, and the consecutive constructions of the hydro-development scheme at the intersection between the two (Figures 3-5). Fincha town itself is a rapidly growing country town that had almost 18,000 inhabitants in 2017 [28]. It is located at the top of a steep escarpment at an altitude of $2300 \mathrm{~m}$ above sea level, close to where the surface drops from the highland plateau into the 
valley of the Blue Nile almost $1000 \mathrm{~m}$ deeper. The area on the plateau had formerly been a wetland with swampy valleys, including the valley of the upper Fincha River, one of the tributaries of the Blue Nile. The three main dams of the scheme have all been built close to the edge of the escarpment at an altitude of about $2300 \mathrm{~m}$, so that the upstream valleys on the plateau were turned into reservoirs for water storage. The irrigated lands in the lower Fincha valley lie at altitudes between 1300 and $1500 \mathrm{~m}$, which provide suitable conditions for sugar cane cultivation. Technically, the three dams are medium-scale structures serving multiple purposes. The height of Fincha dam is $25 \mathrm{~m}$, with an initial hydroelectric capacity of $134 \mathrm{MW}$, while Neshe dam is $38 \mathrm{~m}$ high, producing $95 \mathrm{MW}$. The Fincha dam reservoir is by far the biggest of the three, with a capacity of 650 million cubic meters and a surface of 345 square kilometers. It is a multi-purpose dam, which is used for energy production and irrigation, supplying a power station and a large sugar cane plantation of 19,000 hectares down in the valley [29,30].

The three stages of this hydro-development project resulted in an all-embracing transformation of land use, property rights, settlement patterns, and livelihoods. Traditional land use before construction of the dams consisted of a combination of small-scale agriculture and transhumant animal husbandry on communal pastures in the highlands and along the lower escarpment. The bottom of the valley $1000 \mathrm{~m}$ below the escarpment had formerly not been used for pasture and cultivation, because it was infested by tsetse flies and trypanosomiasis. The implementation of the hydro-development schemes required the resettlement of a substantial part of the local population. Exact figures are difficult to find, but the available data indicate that the number of resettled households due to the Fincha dam project is 3115 [31], and, according to the people interviewed for this present study, approximately 1200 in the case of the Neshe dam.

The Fincha-Amerti-Neshe scheme presents an interesting case to study hydro-development from a W-E-F-nexus perspective, not only because of the complexity of the landscape engineering, but also because it exemplifies the embeddedness of hydro-development in the changing political and economic context at national and global levels. Its three successive stages of implementation fall into different historical phases that are characterized by specific geopolitical settings at the global scale, and political regimes at the national scale (Figure 2). These changing global and national constellations left their traces in project design and regional agro-ecological transformation. Here, we will scrutinize these historical and cross-scalar entanglements to explore the changing power dynamics and drivers behind the W-E-F nexus. We argue that the nexus perspective has to be broadened in order to better capture the complexity of change, which we will call "nexus-plus". The nexus perspective addresses the question of how hydro-development changed the relationship between water use, on the one hand, and energy and food production, on the other. The more comprehensive nexus-plus perspective allows us to investigate the drivers and consequences of the project in their intricate entanglement with changing national and international conditions over a period of half a century, and the effects this has had for the local population. 


\begin{tabular}{|c|c|c|c|}
\hline & Monarchy (until 1974) & Derg Military Regime (1974-1991) & EPRDF Regime (since 1991) \\
\hline $\begin{array}{l}\text { Global } \\
\text { political } \\
\text { context }\end{array}$ & $\begin{array}{l}\text { - Italian occupation } 1936-1941 \\
\text { - 2nd world war } 1939-1945 \\
\text { - End of colonialism } 1950 \text { s and 60s } \\
\text { - Cold war period } \\
\text { - Rising US influence } \\
\text { - Global boom of Big Dams }\end{array}$ & $\begin{array}{l}\text { - Soviet and Eastern Bloc influence } \\
\text { - End of cold war } \\
\text { - Growing opposition to large dam } \\
\text { projects worldwide }\end{array}$ & $\begin{array}{l}\text { - US-Western alignment, rising Chinese } \\
\text { influence } \\
\text { - Strategic importance of Ethiopia in "war } \\
\text { against terrorism" } \\
\text { - Economic globalization } \\
\text { - World Commission on Dams (1997) } \\
\text { - Renewed interest in Big Dams }\end{array}$ \\
\hline $\begin{array}{l}\text { National } \\
\text { political } \\
\text { context }\end{array}$ & $\begin{array}{l}\text { - Emperor Haile Selassie } 1930-1974 \\
\text { - Pan-Africanism } \\
\text { - Feudal society } \\
\text { - Slow technological modernization without } \\
\text { social reforms } \\
\text { - Extreme poverty and famines }\end{array}$ & $\begin{array}{l}\text { - Military coup } 1974 \\
\text { - Establishment of authoritarian } \\
\text { socialist military regime } \\
\text { - Establishment of Large state farms } \\
\text { - State-led modernization }\end{array}$ & $\begin{array}{l}\text { - Overthrow of military regime } 1991 \\
\text { - Neoliberal reforms } \\
\text { - Developmental state model } \\
\text { - Ethnic federalism } \\
\text { - Industrialization \& modernization policy } \\
\text { - High economic growth rates } \\
\text { - Renewed interest in hydro-development }\end{array}$ \\
\hline $\begin{array}{l}\text { Land } \\
\text { tenure } \\
\text { context }\end{array}$ & $\begin{array}{l}\text { - All land owned by the Emperor } \\
\text { - Land use rights granted to feudal lords } \\
\text { - Landless peasants }\end{array}$ & $\begin{array}{l}\text { - All land owned by the state } \\
\text { - Expropriation of feudal lords } \\
\text { - Land use rights granted to } \\
\text { peasants }\end{array}$ & $\begin{array}{l}\text { - Constitutionally land owned by the people } \\
\text { but practically controlled by the state } \\
\text { - Land use rights for farmers and private } \\
\text { investors } \\
\text { - Compensation paid for land required for } \\
\text { development schemes }\end{array}$ \\
\hline $\begin{array}{l}\text { Dam } \\
\text { construc- } \\
\text { tion }\end{array}$ & & & \\
\hline
\end{tabular}

Figure 2. Timeline of Ethiopian hydro-development 1930 to present.

\section{Results: The Fincha-Amerti-Neshe Scheme-A Complex Hydro-development Project}

\subsection{First Stage—Fincha Dam 1973 (Figure 3)}

The first dam at Fincha town was completed as early as 1973 with support from the World Bank [32]. At that time Ethiopia was a feudal state under the rule of Emperor Haile Selassie, who was venerated by many of his subjects as an incarnation of God Almighty. Society was split into a very small land-owning elite and a mass of impoverished peasants. Interrupted only by a brief Italian occupation (1936-1941) shortly before the Second World War, the Emperor had exerted the power of an "absolute despot" since 1930 [33]. Despite the prevailing archaic social structures, the political elites and the Emperor himself became increasingly preoccupied by new technologies and modernization based on hydro-development schemes. The local population, and especially the peasants, had no chance to influence or resist this state-led, top-down modernization policy, which had already begun at the turn of the 19th to the 20th century and culminated during Haile Selassie's regime. In this context, dams served not only as physical tools of development, but also as symbols of modernity. The Emperor himself believed that such landmarks of modernization would earn him recognition in the wider world and loyalty in his own country [34]. However, the modern appearance he presented to the outside world did not coincide with his internal politics. He was an autocratic ruler who firmly held all decision-making powers in his hands, and he and the small class of feudal landlords built their wealth on the reckless suppression and exploitation of the peasants. Under these conditions, water-related development was exclusively to the benefit of the political elite and not the rural population [34].

In the 1950s and 60s Emperor Haile Selassie was able to win the support of the United States for plans to develop his country through large-scale water infrastructures. The willingness of the US government to support Ethiopia's ambitious hydro-power and irrigation schemes must be seen in the context of the Cold War of the 1950s and 60s. In the face of this global confrontation, Ethiopia became a reliable partner of the West in its struggle against the communist East, a struggle in which both sides tried to expand their hegemonic influence among the newly independent states in Africa, Asia, and Latin America. One of the proxy war zones of the cold war was the Nile basin, where both the Soviet Union and the US, together with their allies, struggled for control over the region and its lifeline, the Nile River. Emperor Haile Selassie took advantage of this geopolitical context to achieve his own goals in domestic politics and internationally as a leading figure in the Pan-African movement $[32,35]$. 
From the late 1950s, Ethiopia became a strategically important ally of the US in its attempt to confine the growing political influence of communism on the African continent, especially in the face of support of the USSR for the Nasser regime in Egypt and the construction of the Aswan Dam. At the same time, the 1950s to 1970s were the heyday of Big Dam projects worldwide, because they fit so well into the endeavors of the newly independent states for comprehensive state-led development, and into the prevailing modernization paradigm of development. Against this backdrop, the United States responded positively to the request of the Ethiopian government to study and develop the water resources of the Blue Nile [35]. The Fincha dam was the only one approved for implementation out of a number of options that had previously been studied by the US Reclamation Bureau, and its construction started only with considerable delay, because the donors and the Ethiopian government could not agree upon goals and target populations [32].

From the very beginning, the newly established hydro-development schemes in Ethiopia served multiple purposes. The government saw them as tools of modernization, but also as a means of control over remote areas and their inhabitants. Foreign donors happily supported the construction of dams because infrastructure was seen as a prerequisite for economic development, and at the same time these interventions allowed the donors to maintain political influence in the region. As a consequence, large hydro-development projects often had to struggle with conflicting interests, priorities, and objectives. In the case of Fincha, for example, it was an issue as to whether the generated power should benefit rural or urban areas, as a contemporary 1969 World Bank document indicates:

"The prospect is that electricity supply will be confined to population centers for a considerable time to come; there is no significant rural distribution and given the dispersed nature of the agricultural community and its low monetary income the prospect of any rural electrification in the foreseeable future is unlikely." [36] (p. 2)

The above means that under the political conditions of the time, local inhabitants were not supposed to benefit from the large-scale development project, and they were not included in its design and implementation at all. The people of Fincha still recall the authoritarian style of development in the early days of the project. When asked whether they were consulted during the dam construction, one of the respondents gave the following account:

"In 1962 some white people from Germany came here by helicopter and planted measuring equipment on Amerti, Fincha and Neshe rivers. In 1965, the government designed the projects, and in 1968 the Fincha dam was constructed. They never consulted the local people. We had no information or say on the dam". (Key informant displaced by Fincha dam)

The construction of Fincha Dam and the flooding of the valley for the creation of the large Chomen lake reservoir had a number of serious consequences for local communities. Project documents from that time, including those of the World Bank, hardly ever mention local communities and the impact of the dam on their livelihoods. They describe the area as if it was just an uninhabited swamp. The very nature of the "state", the absolute power of the Emperor, his control over everything, and the total submission required by his subjects reduced the locals to invisible, movable, and non-threatening subjects.

Part of the reason why the Emperor's government was able to do whatever it wanted to was its total control over the land. Locals recall that only the landlords were consulted and promised some compensation, but this did not involve the peasants:

"They (the government) called the landlords ('Qoro' in local language) from the whole district to a meeting at Nekemt, and there they signed the agreement. Then the plane came to our area and took pictures, and they designed the project. We heard little about the issue. People said the landlords had sold the land." (Key informant displaced by Amerti and Neshe dams)

During the late days of the Emperor, the issue of land ownership and property rights in Ethiopia became increasingly critical. As in all other parts of the country, the agricultural land in the study area 
at Fincha was controlled by the ruling elite, while the peasants were landless tenants without any legal title [37]. Even the absentee landlords, members of the nobility, had only conditional rights, since their access to land depended on their loyalty to the state. The government could grant land holdings as a reward, but could also take them away if beneficiaries fell into disgrace [38]. The peasantry was obviously at the lowest end of the power hierarchy, since it often happened that landlords evicted their tenants when the land was appropriated for development purposes. The state had a constitutional right over land now owned by anyone, which included communal grazing lands [38]. Given these situations, there was no chance of debating the prevailing order set by state actors [37]. Overall, the period was characterized by a drastic power imbalance between the landlords and the peasants, while the emperor himself used his control over the land as a divide and rule mechanism to control his nobilities. Peasants had the highest level of insecurity in respect of their land rights during this period. As a result, a large number of peasant households were displaced by the Fincha Dam, with no compensation at all being paid, and no chance to complain.

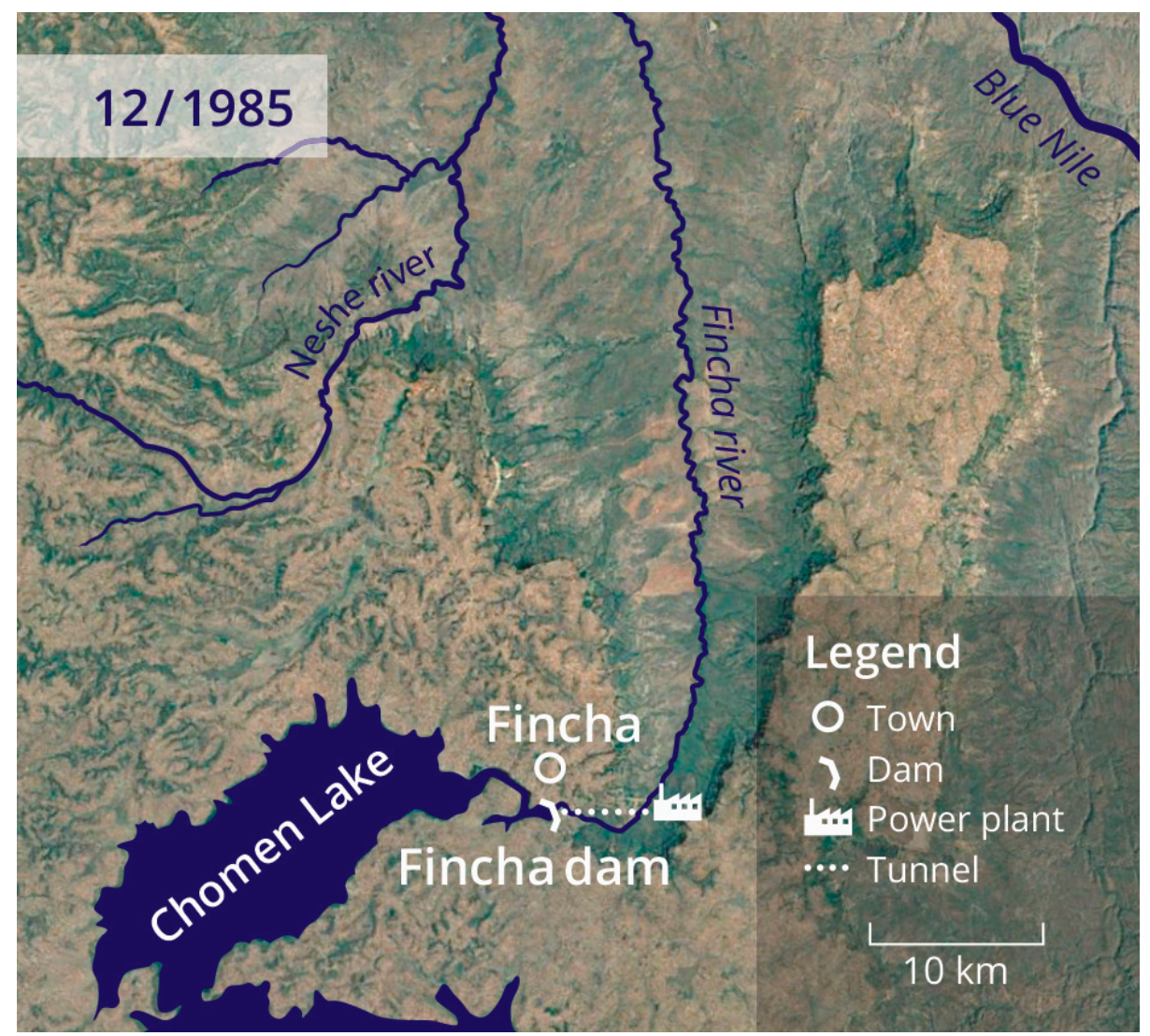

(Source: Google Earth/ Landsat/Copernicus)

Figure 3. The study site after completion of Fincha dam (1973) in December 1985.

\subsection{Second Stage-Amerti Reservoir 1987 (Figure 4)}

The second, much smaller project was the construction of the Amerti dam and reservoir, which was completed in 1987. Historically, the political and economic conditions of that time were fundamentally different from the previous phase. In the years between 1974 and 1991, Ethiopia was under the rule of the Derg, a socialist military regime which had started with the overthrow of the Emperor, the elimination of the old feudal elites, and a radical shift of its global political orientation from the West to the East. When the Derg seized power, it was at first welcomed by the peasants who put great faith in the revolutionary promises [38]. With Soviet-style Marxism-Leninism as its new ideological guideline, the government did indeed initiate a number of radical social and economic 
reforms. However, this went along with terrible bloodshed, the infamous "Red Terror", and military interventions in Eritrea. When the US supported a Somali attempt to annex part of southeastern Ethiopia, the military regime turned towards the communist countries in order to secure military aid against Somali aggression and Eritrean guerilla fighters [39,40]. The Soviet Union became the patron of social and economic transformation and at the same time the model for Ethiopia's development pathway [34]. Following this model, the government implemented a "land to the tiller" program which transferred land-use rights from the feudal landlords to the peasants. The establishment of large state farms and cooperatives, a comprehensive resettlement and villagization program, and the nationalization of estates and industries were key elements of the state capitalism implemented by the Derg [40]. However, this state-centered modernization strategy went along with a renewed centralization of power in the military-controlled administration, central planning, and exploitation of the country's resources by the state, including water, land, and the labor power of the peasants [41].

Altogether, the late 1970s and 1980s saw a sharp drop in dam construction activities, not only in Ethiopia, but worldwide. This was partly due to the general political orientation of the Derg regime, but partly also to an increasing opposition to large dams at the global scale. Skepticism in respect of large dams was to some extent a response to the negative consequences of mega-projects like the Aswan High Dam, and it also reflected a return of prevailing development discourses to "small is beautiful". In addition, the experience of economic crisis and structural adjustment left little space for the risky development adventures of large expensive projects. All this affected Ethiopia's hydro-politics substantially and led to a relatively quiet period with regard to dam-building activities.

While Soviet development assistance concentrated on the southern part of the country and contributed to the construction of Melka Wakena Dam on Shebele River [32], the United States and Western donors supported water sector developments on the Blue Nile. In this political environment, the decision was made to add another small construction to the Fincha scheme, which was more an extension of the already existing infrastructure than a completely new project. The Amerti dam, which was financed by the European Economic Community, helped to increase the storage capacity and energy production of the Fincha dam by creating an additional reservoir [42]. And a new state farm was established in the lowland areas downstream of the Fincha hydro-power dam, which was originally used for maize production and later integrated into the large sugar cane plantation [29].

The two groups of international donors from the East and the West agreed that an increase in energy production was a prerequisite for strengthening the ailing economy and for enhanced economic growth [43]. Despite its initial pro-poor and pro-people rhetoric, the Derg maintained its interest in expanding the state's extractive policies and went on to construct the additional water reservoir on Amerti River. In what appears as the order of the day, the inhabitants of the area were not consulted in the planning process. Although some farmers were later compensated for the land they had lost due to the construction of the Amerti reservoir, many were left uncompensated and had no chance to complain. The locals say the process of demanding compensation was so intimidating and poorly organized, that many people did not dare to raise their voices, as was stated in one of our interviews.

“The local administrators went away with whatever they wanted to do. When someone asked for compensation, he would be labelled as anti-developmental and put in prison, or could even be killed in front of the people. We were like oxen tied around the mouth; we could not talk at all. We were forced to be silent." (Key informant displaced by Amerti dam) 


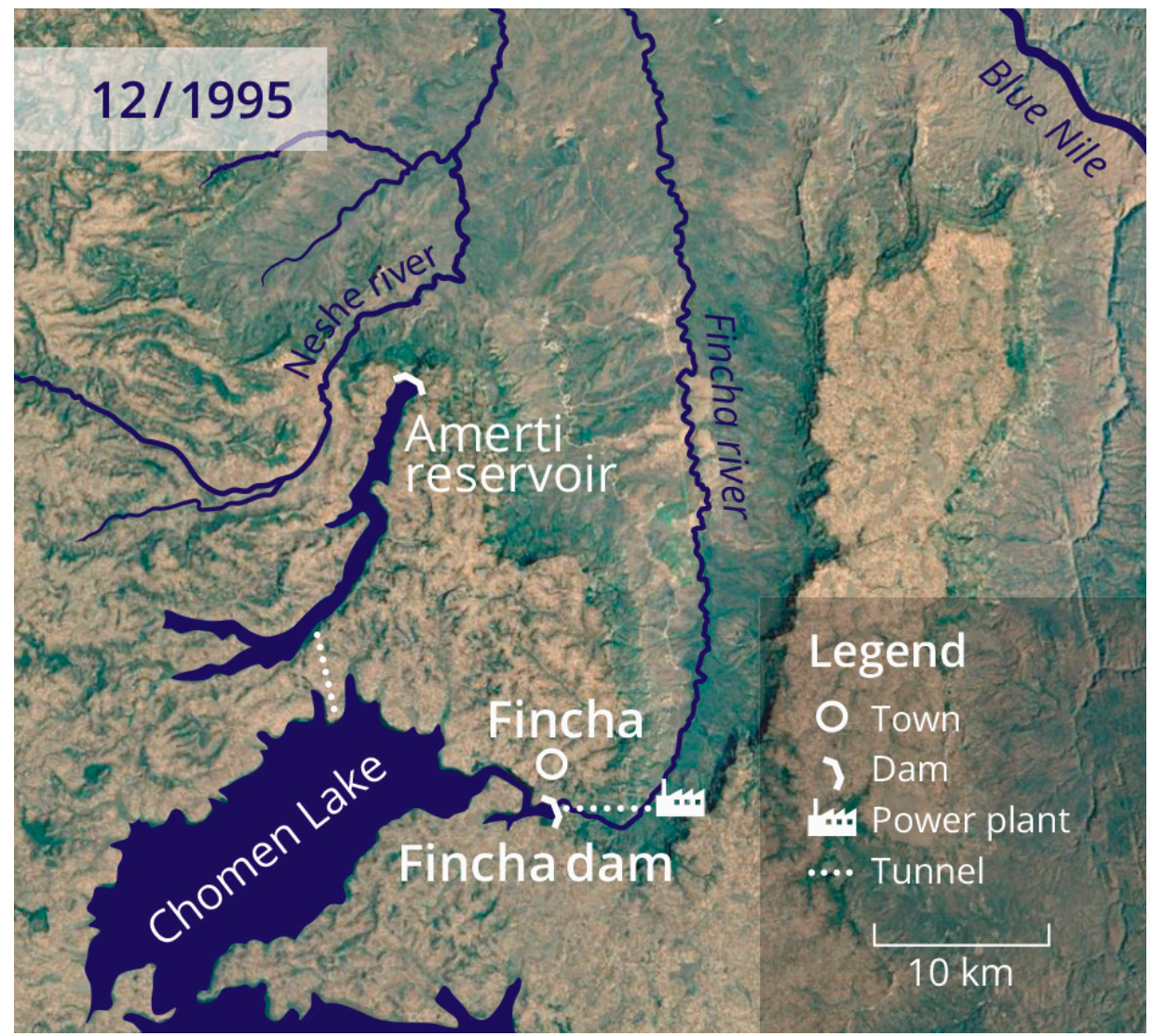

(Source: Google Earth/ Landsat/Copernicus)

Figure 4. The study site after completion of the Amerti dam and reservoir (1987) in December 1995.

\subsection{Third Stage-Neshe Dam 2012 and the Completion of the Fincha-Amerti-Neshe Scheme (Figure 5)}

The third stage of hydro-development in Ethiopia saw a remarkable reinvigoration of the Big Dam paradigm and an expansion of irrigated agriculture. The present map of the country's dams, hydro-electric power stations and large-scale irrigation schemes (see Figure 1) was shaped to a large extent only after the beginning of the new millennium. The most spectacular projects, like the Grand Ethiopian Renaissance Dam (GERD) on the Blue Nile, or the Gilgel Gibe III dam, are still under construction, together with a number of smaller ones. The political precondition for this paradigm shift was the overthrow of the socialist Derg regime by a coalition of parties that formed the Ethiopian People's Revolutionary Democratic Front (EPRDF) in 1991. Under EPRDF rule, the country opened up again to the West and to Western development funding, became an important strategic ally in the so-called "war against terrorism", and was integrated in economic globalization, with rather ambiguous consequences. Recently, the role of China has become more prominent in Ethiopia, as all over the African continent, which has given an additional impetus to economic growth and infrastructure development. In this context, the Ethiopian government's renewed interest in dam construction coincides with the reassessment of Big Dams under the auspices of the World Commission on Dams, which, under the patronage of Nelson Mandela, delivered an influential report on the achievements and shortcomings of large dams [44].

The EPRDF government skillfully used the opportunities offered by its strategic bargaining power, the availability of alternative donors like China, and sufficient access to funding, to reinvigorate its policy of modernization. In line with these general political orientations, large dams became flagship programs of the developmental state. The name of the Grand Ethiopian Renaissance Dam can be taken as a programmatic notion that emphasizes the highly symbolic meaning of dam construction in the government's dream of "high modernity" [45]. The GERD, formerly called the Millennium Dam, will 
be the largest dam on the African continent once it is completed. The developmental-state orientation of the EPRDF views dams as essential tools for the transformation of the national economy towards a middle-income country, which is seen as a renaissance of Ethiopia's glorious past $[23,46]$.

The national program on dam construction and hydro-power generation in Ethiopia follows three objectives that all contribute to the country's ambitious growth and development strategy, i.e., the provision of energy for industrialization and urban centers, export of surplus energy to neighboring countries to increase state revenues [47], and the expansion of irrigated agriculture for food production and exports. Ethiopian energy production multiplied tenfold from $400 \mathrm{MW}$ in 1991 to over $4000 \mathrm{MW}$ at present, and it is expected to reach more than 10,000 MW in the near future after the completion of Gilgel Gibe III and the GERD. At the same time, national sugar production has also increased considerably. Since 1991 the number of large sugar factories has risen from two to eight, and annual production from 150,000 tons a year to well over 300,000 tons a year, with an increase of the planted area from 15,000 ha to more than 100,000 hectares. The plan is to further raise the number of sugar factories to 13 and the annual yield to 2 million tons [29].

In line with the national growth and development strategy, Neshe Dam was completed in 2011 as the third reservoir in the Fincha-Amerti-Neshe scheme. Construction works were mainly carried out by Chinese companies, and $85 \%$ of the construction costs of 137 million US $\$$ were covered by a loan from the Chinese EXIM Bank [48]. The already existing state farm at Fincha, that had hitherto primarily produced grain, was converted to sugar cane and integrated in the sugar plantation, which gradually grew from 6000 to almost 20,000 hectares [29]. The Neshe Dam was built at a time when dams and their social and environmental impacts were seen positively, coming ten years after the report by the World Commission on Dams. The Commission's report criticizes massive displacements and other harmful social and environmental effects of dams, but it also highlights their economic benefits and advises that local populations should be better involved and compensated in order to make dams socially beneficial. The Ethiopian government officially acknowledged the WCD report, but even so, things did not work out as they should have, as the example of the Neshe project shows.

In connection with this scheme, communication with the local population was better than during the previous projects, but according to local experts, community participation was still insufficient. A few consultative village meetings were held, but even so a number of serious problems arose that finally led to open resistance against the project.

One of the respondents recalls the process as follows:

“Dam construction started in July 2010. They selected some individuals, mostly group leaders, and informed them of the plans. Only people working in the village administration and some who were close to them got notice of the issue. There was no consultation with the whole community. We heard that huge compensations were promised including nice houses with modern facilities like showers and electricity, and 10 years subsistence allowances. They also promised us that they would provide two hybrid cows per household. Then the community surrendered, because they cannot fight the government, and they believed in the promised compensation." (Key informant displaced by Fincha-Amerti-Neshe dam)

As seen here, people complain about two things. First, there is a general feeling of unfairness, because apparently information about the new project and its opportunities was not made generally available. Secondly, and worse than that, many people complain about broken promises and disappointed expectations, especially with regard to the payment of compensation and the organization of the out-grower scheme adjacent to the sugar cane plantation. Many respondents confirmed that compensation for land that was taken for the new dam was not paid as originally agreed, which, as they explain, was due to insufficient asset valuations, incorrect surveys, mismanagement, and corruption.

Tensions in connection with the project were further aggravated when some of the resettled families realized that the new houses they had been given in the lowland area close to the sugar cane plantation were not as nice as they had expected, and that living conditions in that location were not 
favorable. For that reason, many families left the new settlement again and went back to the highlands. They abandoned their new homes and the land they had been given. However, as out-growers they were no longer free in their decision about what to cultivate and where to live, but had to grow sugar cane for the factory. In 2017, when the farm managers of the sugar cane plantation realized that the land of the out-growers was no longer cultivated, they started to plant it with sugar cane. This again caused a major uproar among the settlers who claimed that the sugar company should pay rent to them. The company did so in the first year, but when it refused to do so in the second year, people threatened that they would burn the plantation and attack the factory. As a consequence, almost 2000 hectares of the out-grower scheme were left without cultivation.

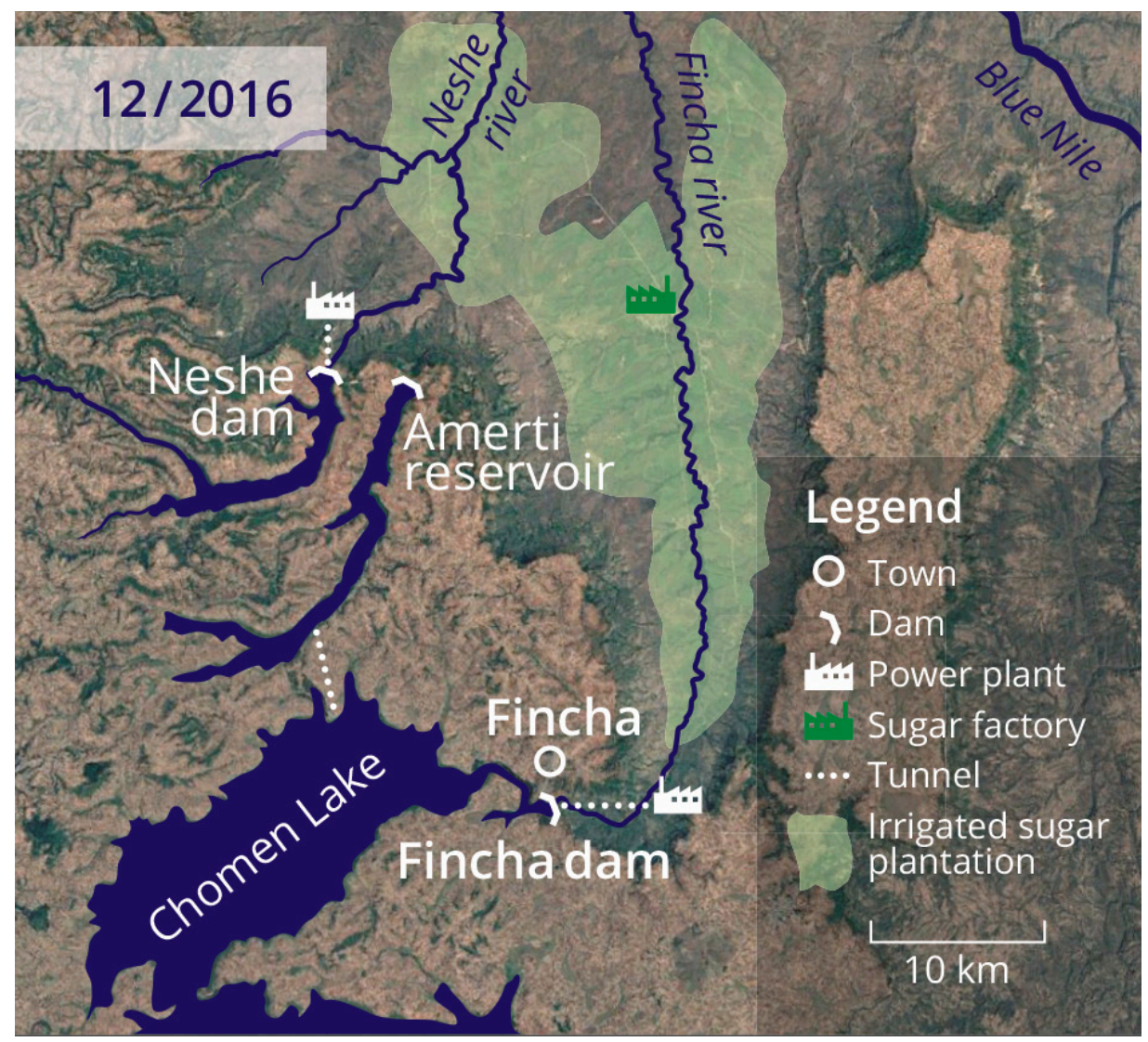

(Source: Google Earth/ Landsat/Copernicus)

Figure 5. The study site after completion of Fincha-Amerti-Neshe scheme (2012) in December 2016.

\subsection{Livelihood Changes}

From a local level perspective, the diverse processes of hydro-development described above have affected local communities and their livelihoods in multiple ways, most notably by changing access to land, and to a lesser degree also to water. The Fincha-Amerti-Neshe scheme forced many people to abandon their land, leave their homes, and look for other sources of income. It led to a more or less involuntary transformation of farming practices, and left people with a feeling of insecurity and powerlessness. Farmers in the study area often perceived the multiple interventions as severe disruptions of their livelihoods, an increase of risk, and a loss of control. In the world of farmers, land is essential not only as an asset, but as the foundation of their livelihoods and identity. These perceptions and emotions are best captured in the words of the people themselves, as for example in the following quote from an interview with a village official: 
"Farmers do not want to give their land away, not even to their brothers and sisters. They were resettled by force, against their will. So their life is trapped. If you have no land, what can you do as a farmer?" (Village official)

It is therefore not surprising that many farmers complain about the loss of land, even in cases where they had received (smaller) irrigated fields in return, or financial compensation. The value of the land involves more than just a price that can be compensated. This explains why the interviews with local people frequently reveal experiences of loss and misery, which are almost a standard narrative, as in the following quotes:

"I once owned 6 hectares of farm land. Now I am left with nothing. I am forced to work as daily labourer to support my children." (Key informant displaced by Amerti and later by Neshe dam)

"In the past, rich people would own up to 40 hectares and the poor households would own not less than 5 hectares. But now, after our land has been taken by the dams, the size of land holdings decreased. Many have no land at all. Today those who are considered rich own less than 2 hectares of farm land." (Focus group discussion with community members affected by Fincha Dam)

In addition to the loss of farm land, the confiscation of communal grazing areas also contributed to the locally experienced impact of hydro-development. In the traditional agro-pastoral economy, pasture land was an essential common pool resource. No compensation was paid for the communal grazing areas, and there were no alternative pastures elsewhere. As a consequence, the number of livestock had to be significantly reduced, with negative effects on household incomes and the local consumption of milk and meat. The following quotes indicate how this interference with the traditional land use system increased the vulnerability of households:

"Before the dams came, we had enough land and produced a lot. We used to store what we produced in a good season, sometimes for several years. Many households had 3 or 4 pairs of oxen and more than 10 milking cows. Following the dams, we lost our farm land, and now we struggle to produce sufficient food for our day to day needs, let alone storage for the next season. We also lost our livestock; today many own less than 5 cattle. Our food security situation is getting worse." (Farmer who had been displaced by Amerti and later by Neshe dam)

"What we produce cannot even cover the cost of production. In the past, productivity was high. But now land size and productivity are declining. Many people do not have enough to eat. What is worse is that we are unable to give a better life to our children. We are facing huge problems, but have no choice." (Focus group discussion with community members affected by Fincha dam)

"Most farmers run out of food during the summer season. Our production is just from hand to mouth, it is hardly enough for our needs. All these problems came with the construction of the dam." (Farmer displaced by Fincha Dam)

In addition to land loss, hydro-development also had detrimental effects on drinking water supply. Traditionally the people used to fetch drinking water from springs, which were lost in the large reservoirs. The following quotations describe the ensuing challenges:

“The dam caused damage to many springs and small streams. As a result, people suffer from a lack of clean water. Some travel long distances to get drinking water. Some also dig underground wells. Or they take the water from the lakes. But this is causing health problems mainly due to droppings of the large birds living in the surroundings of the dam." (Focus group discussion near Fincha Dam) 
"Amerti dam swallowed the natural springs such as Dongoro, Yaantoo; and the tributary rivers such as Shaatii, Goda Walee, Goda Buqqee, and others. We formerly used the springs to get drinking water. Now we are forced to drink water from the dam causing many water borne diseases like typhus, malaria, and others. Our livestock is also affected by many diseases caused by this dam." (Key informant affected by Amerti Dam)

Access to irrigation water is another contested issue. Only the recipients of plots inside the Neshe irrigation scheme are allowed to use it, while all others are denied access. For them, the dam has mainly disadvantages:

"Few people use irrigation, but we all have a problem to get access to the market. The dam blocked the only road that we had. Now the distance to the market, the grain milling machine and social services is much longer. We are surrounded by water." (Focus group discussion with a community near the Fincha reservoir)

"The rivers that communities used for irrigation are taken by the dam. The hydro-power station does not allow farmers to use the water of the dam as it affects the capacity of generating power, and also in fear of the siltation problem." (Village administration official)

The uneven distribution of benefits and disadvantages of the hydro-development scheme can also be seen in respect of energy production. Despite a total capacity of the hydro-power plants at Fincha-Amerti-Neshe of close to $240 \mathrm{MW}$, most households do not have access to the national grid.

"We live under the nose of the dam, but we could not get electricity. We hear that the country even exports electric power to Djibouti and other countries." (Community member living near Neshe Dam)

"We have given the project all that we have, but they denied us to provide electric power at least. We are living in the darkness." (Community member living near Amerti reservoir)

\section{Discussion: Broadening the View towards a Nexus-Plus Perspective}

The example of the Fincha-Amerti-Neshe scheme illustrates how hydro-development projects change the complex linkages and mutual relationships between water, energy, and food security. The W-E-F nexus approach addresses these relationships with the aim of improving resource use efficiency. This paper argues that the approach has its merits for describing the managerial aspects of water, energy and food, but it does not sufficiently capture the relational aspects and complex causes of mismanagement, inefficiency and distortions. The conceptual shortcomings have already been mentioned in the second chapter of this paper by referring to critical debates that see the W-E-F nexus as immature, incomplete, and unpolitical. If nexus thinking wants to live up to its commitment to "improving living conditions and livelihood opportunities for the "bottom of the pyramid"" [7], it is important to understand the linkages between the micro-dynamics of land tenure and large-scale water infrastructure developments. Therefore, this article calls for a broadening of the perspective towards a nexus-plus approach that explicitly includes the analytical dimensions of time, scale and power. The intention of this conceptual modification is to add a more relational focus to the assessment of water use and distribution.

The time dimension is essential for an understanding of hydro-development as a historical process. The present landscape of dams, hydro-power stations, and factories in Ethiopia is the outcome of a long history of development activities. Ethiopian policies in respect of hydro-power have been driven by different models of development and patterns of water governance, which have all left their traces in the country's infrastructure. Our historical account of the Fincha-Amerti-Neshe scheme shows how three consecutive political regimes have molded the material structures that are still in use today. These structures remain in place even after the conditions under which they were created cease to exist. 
Like the layers of an archeological site, the hydro-development landscape can be read as a collection of historical legacies, which shape the conditions under which people are living today, and even in the future. Due to their longevity, infrastructure projects tend to shape pathways for future development which cannot easily be altered, and which therefore may lead to perpetuation of past conditions in the future through current processes and concepts. The return of the Big Dam paradigm after the beginning of this millennium, for example, does not only dominate the current stage of hydro-development, but it will have long-lasting consequences for future energy production and agriculture in the region.

Another observation that is clear from this study of the Fincha-Amerti-Neshe scheme is the remarkable continuity in the difficult relationship between the local population and the government. Despite the radical regime shifts from monarchy to socialism to neoliberal capitalism, Ethiopia has long had the character of an authoritarian developmental state, even before the current EPRDF government. In the course of the three consecutive regimes, the government gradually improved the legal status of farmers and their land ownership rights, to the extent that farmers are now granted compensation for land sequestered for dam construction. But even so, in the perception of the rural population the state remains a distant absolute power that dominates the countryside without much concern for the interests of rural populations. From the point of view of the people affected by hydro-development projects, it does not make much difference whether they lose their land to a socialist or a capitalist government.

Regarding the scalar dimension, we have shown that the construction of the Fincha-Amerti-Neshe scheme is deeply embedded in national, but also in international and even global contexts. Ethiopian hydro-development was never aimed at improving local livelihoods, but at national targets of energy and food production, higher exports and economic growth. The socialist Derg regime initially made promises to the peasants that they would be granted land titles, but in practice this did not lead to stable ownership. Under the present EPRDF government, farmers do have more freedom and better legal conditions, but this does not protect them against resettlement, land loss, and higher vulnerability. All through the last three regime eras, micro-level land right dynamics have been a defining factor that determines how water infrastructures influence local livelihoods [49]. The last half century in Ethiopia has been characterized by a state with almost absolute power over access to and disposal of land $[38,50]$. Throughout the three regimes, farmers were vulnerable to revocation of their land rights by others, including the state itself. Despite the government's social equity rhetoric, the experience of recent years clearly indicates that the state still retains control over the land and uses it to collect rent by transferring use rights to foreign investors [51]. Throughout the three political regimes, the Ethiopian government has used dams and hydro-developments to alienate land from local communities without proper compensation.

In the end, understanding these power relations is essential to explaining the underlying problem for which the nexus approach seeks a solution, i.e., the aggravation of water scarcity. This case study has shown that scarcity does not simply emerge from limited resource availability, but from the competition between different sectors in the national economy, and between specific interests across scales. Scarcity is therefore not just a natural phenomenon, but a problem of resource rights, entitlements, and governance. As in other parts of the Global South, Ethiopian hydro-development was heavily dependent on foreign finance [44], which largely determined the design of the projects. At different stages of the Fincha-Amerti-Neshe scheme, foreign support came from the United States, the Soviet Union, and more recently from Western donors and China, with the involvement of the World Bank, and the African Development Bank [35,52]. Such foreign support has enabled the Ethiopian governments to escape domestic accountability pressures and act independently [53]. As a result, they have done relatively little to benefit the local farming population.

The call for a more comprehensive and socially inclusive approach derived from the case study of the Fincha-Amerti-Neshe scheme is in line with the recommendations of the World Commission on Dams, which was based on the study of several thousand large dams [54]. 


\section{Conclusions}

This case study of the Fincha-Amerti-Neshe scheme shows how closely water-related developments are embedded in political and economic contexts at the national and global levels. The nexus approach provides a framework for the study of these connections with a focus on the distributional logics of water governance under conditions of scarcity. Aiming at an enhancement of resource use efficiency, the W-E-F nexus addresses the question to what extent the country's water resources should be used for energy production or for irrigated agriculture. This issue is obviously of high strategic importance for Ethiopia's development, because the sustainable use of scarce water resources requires an understanding of the relationship between the competing demands, interests, and actors involved, and it does so at the national as well as at the international level. However, the paper argued here that the W-E-F nexus perspective does not sufficiently capture the political nature of hydro-development, for example with regard to the causes of water scarcity, and the disadvantages suffered by local populations.

As a consequence, the paper calls for a broadening of the nexus perspective beyond the managerial dimensions of water, energy and food. It argues that the study of water-related developments should also address time, scale and power as analytical dimensions. Combining these analytical and managerial dimensions in what we call a nexus-plus approach should provide a deeper understanding of the causes and problems of water scarcity, and a more comprehensive way of dealing with them.

The practical value of a nexus-plus perspective for decision making lies in an alternative governance approach that gives more importance to inclusiveness, social equity, and participation. Learning from the controversial history of the authoritarian, top-down implementation of the Fincha-Amerti-Neshe scheme, decision makers should realize that successful and sustainable rural development requires the active involvement of local populations. For farmers, land is more than just an asset for production, it has a highly symbolic meaning. In participatory rural development there should be no confiscation without compensation. The people in the study area urgently demand security of land and water rights. Close ties between government authorities, development organizations and local communities require reliability and trust. A prerequisite for this is the keeping of earlier promises, together with a more active involvement of village communities and their local organizations, and improvements of local infrastructure such as roads. What many people in the Fincha area have been waiting for since the beginning of hydro-development half a century ago is a fair share in the benefits of the projects. This is not only a matter of money and compensation, but also of access to electricity, to employment in the sugar plantation and factory, and to markets. Hydro-development based on a complex nexus-plus perspective acknowledges the economic as well as the social dimensions of change. Based on historical experience, it makes a strong point for inclusive, fair, and equitable governance of scarce resources like land and water.

Author Contributions: The two authors have contributed equally to all the sections of the paper. D.M.-M. was responsible for funding acquisition, project administration and supervision, while M.G. supervised the field work in Ethiopia and the data administration. The conceptualization and writing of the paper was jointly done by both authors.

Funding: This research was funded as part of a Belmont Forum Collaborative Research Action on Mountains as Sentinels of Change (CRA - 296 NILE-NEXUS) entitled "Opportunities for a sustainable food-energy-water future in the Blue Nile Mountains of Ethiopia".

Acknowledgments: We would like to acknowledge our NILE-Nexus research team, Benjamin Zaitchik, Belay Simane, Paul Block, Jeremy Foltz, Gianni Gilioli, Andrea Sciarretta and Davide Bazzana, for their overall support, Yeshe Jema for conducting the field interviews, Irene Johannsen for drawing Figures 1 and 2 and refining Figures 3-5, Yannick Noël for drafting Figures 3-5, and Ruth Schubert for proof reading the manuscript. The authors also wish to thank the three anonymous reviewers for their valuable comments.

Conflicts of Interest: The authors declare no conflicts of interest.

\section{References}

1. WEF. Water Security: The Water-Food-Energy-Climate Nexus; Island Press: Washington, WA, USA; London, UK, 2011. 
2. Allouche, J.; Middleton, C.; Gyawali, D. Nexus Nirvana or Nexus Nullity? A Dynamic Approach to Security and Sustainability in the Water-Energy-Food Nexus; STEPS Centre: Brighton, UK, 2014.

3. Wichelns, D. The water-energy-food nexus: Is the increasing attention warranted, from either a research or policy perspective? Environ. Sci. Policy 2017, 69, 113-123. [CrossRef]

4. Leese, M.; Meisch, S. Securitising Sustainability? Questioning the'Water, Energy and Food-Security Nexus': Securitising Sustainability? Questioning the'Water, Energy and Food-Security Nexus. Water Altern. 2015, 8, 695-709. Available online: http://health21magazine.com/wp-content/uploads/2017/08/2015-Water-Energyand-Food-Security.pdf (accessed on 18 September 2018).

5. Johnson, O.W.; Karlberg, L. Co-exploring the Water-Energy-Food Nexus: Facilitating Dialogue through Participatory Scenario Building. Front. Environ. Sci. 2017, 5, 123. [CrossRef]

6. Karlberg, L.; Hoff, H.; Amsalu, T.; Andersson, K.; Binnington, T.; Flores-López, F.; Bruin, A.D.; Gebrehiwot, S.G.; Gedif, B.; Zur Heide, F.; et al. Tackling complexity: Understanding the food-energy-environment nexus in Ethiopia's Lake Tana Sub-basin. Water Altern. 2015, 8, 710-734.

7. Hoff, H. Understanding the Nexus. In Proceedings of the Background Paper for the Bonn 2011 Conference: The Water, Energy and Food Security Nexus, Stockholm, Sweden, 16-18 November 2011.

8. Manuel-Navarrete, D. Double coupling: Modeling subjectivity and asymmetric organization in social-ecological systems. Ecol. Soc. 2015, 20. [CrossRef]

9. Rasul, G. Managing the food, water, and energy nexus for achieving the Sustainable Development Goals in South Asia. Environ. Dev. 2016, 18, 14-25. [CrossRef]

10. Turner, M.G. Landscape Ecology: What Is the State of the Science? Annu. Rev. Ecol. Evol. Syst. 2005, 36, 319-344. [CrossRef]

11. Holling, C.S. Resilience and Stability of Ecological Systems. Ann. Rev. Ecol. Syst. 1973, 4, 1-23. [CrossRef]

12. Meadows, D.H. The Limits to Growth: A Report for the Club of Rome's Project on the Predicament of Mankind Donella H. Meadows ... ; Universe Books: New York, NY, USA, 1972.

13. WCED. Our Common Future; Oxford University Press: Oxford, UK, 1987.

14. Berkes, F.; Colding, J.; Folke, C. (Eds.) Navigating Social-Ecological Systems: Building Resilience for Complexity and Change; Cambridge University Press: Cambridge, UK; New York, NY, USA, 2003.

15. Brand, U. How to Get Out of the Multiple Crisis? Contours of a Critical Theory of Social-Ecological Transformation. Environ. Values 2016, 25, 503-525. [CrossRef]

16. O'Keefe, P.; Westgate, K.; Wisner, B. Taking the naturalness out of natural disasters. Nature 1976, 260 , 566-567. [CrossRef]

17. Mehta, L.; Leach, M.; Scoones, I. Editorial: Environmental Governance in an Uncertain World. IDS Bull. 2001, 32, 1-9. [CrossRef]

18. Benson, D.; Gain, A.K.; Rouillard, J.J. Water Governance in a Comparative Perspective: From IWRM to a 'Nexus' Approach? Water Altern. 2015, 8, 756-773.

19. Allouche, J.; Middleton, C.; Gyawali, D. The Water-Food-ENERGY Nexus: Power, Politics and Justice; Pathways to sustainability series; Routledge Taylor \& Francis Group: London, UK; New York, NY, USA, 2019.

20. Midgley, S.J.E.; New, M.; Methner, N. Competition for Land, Water and Energy (Nexus) in Food Production. In Encyclopedia of Food Security and Sustainability; Elsevier: Amsterdam, The Netherlands, 2019; Volume 1, pp. 187-195.

21. Hermann, S.; Welsch, M.; Segerstrom, R.E.; Howells, M.I.; Young, C.; Alfstad, T.; Rogner, H.-H.; Steduto, P. Climate, land, energy and water (CLEW) interlinkages in Burkina Faso: An analysis of agricultural intensification and bioenergy production. Nat. Resour. Forum 2012, 36, 245-262. [CrossRef]

22. Howells, M.; Hermann, S.; Welsch, M.; Bazilian, M.; Segerström, R.; Alfstad, T.; Gielen, D.; Rogner, H.; Fischer, G.; van Velthuizen, H.; et al. Integrated analysis of climate change, land-use, energy and water strategies. Nat. Clim. Chang. 2013, 3, 621-626. [CrossRef]

23. Mosley, J.; Watson, E.E. Frontier transformations: Development visions, spaces and processes in Northern Kenya and Southern Ethiopia. J. East. Afr. Stud. 2016, 10, 452-475. [CrossRef]

24. Leck, H.; Conway, D.; Bradshaw, M.; Rees, J. Tracing the Water-Energy-Food Nexus: Description, Theory and Practice. Geogr. Compass 2015, 9, 445-460. [CrossRef]

25. Allouche, J.; Middleton, C.; Gyawali, D. Technical Veil, Hidden Politics: Interrogating the Power Linkages behind the Nexus. Water Altern. 2015, 8, 610-626.

26. CSA. The 2007 Population and Housing Census of Ethiopia; CSA: Addis Ababa, Ethiopia, 2007. 
27. CSA. Population Projection of Ethiopia for All Regions at Woreda Level from 2014-2017; CSA: Addis Ababa, Ethiopia, 2013.

28. Wirtu, M. Urban Households' Domestic Water Demand and Supply: The Case of Fincha Town, Abay-Chomen Woreda, Horo Guduru Wollega Zone, Oromia Regional State, Ethiopia. Master's Thesis, Haramaya University, Haramaya, Ethiopia, 2017.

29. ESC. Finchaa Sugar Factory. Available online: http://www.ethiopiansugar.com/finchaa-sugar-factory/ (accessed on 4 July 2019).

30. FAO. Dams: Ethiopia. Available online: http://www.fao.org/nr/water/aquastat/dams/index.stm (accessed on 19 July 2019).

31. Olana, B. People and Dams: Environmental and Socio-Econoic Changes Induced by a Reservior in Fincha'a Watershed, Western Ethiopia; Tropical Resource Managment Papers No. 75; Wageningen University and Research Centre: Wageningen, The Netherlands, 2006.

32. Carr, C.J. River Basin Development and Human Rights in Eastern Africa-A Policy Crossroads; Springer Open: Cham, Switzerland, 2017.

33. Levine, D. Haile Selassie's Ethiopia: Myth or Reality? Afr. Today 1961, 8, 11-14.

34. Clapham, C. Ethiopian Development: The Politics of Emulation. Commonw. Comp. Polit. 2006, 44, $108-118$. [CrossRef]

35. Sneddon, C. Concrete Revolution: Large Dams, Cold War Geopolitics, and the US Bureau of Reclamation Christopher Sneddon; The University of Chicago Press: Chicago, IL, USA, 2015.

36. IBRD/IDS. Appraisal of the Finchaa Hydroelect'ric Project of the Ethiopian Electric Light and Power Authority; IBRD/IDS: Ethiopia, 1969; Available online: http://documents.albankaldawli.org/curated/ar/ 297171468036327837/pdf/multi-page.pdf (accessed on 2 September 2019).

37. Hultin, J. Rebounding Nationalism: State and Ethnicity in Wollega 1968-1976. Africa 2003, 73, 402-426. [CrossRef]

38. Rahmato, D. Land rights and tenure security: Rural land registration in Ethiopia Dessalegn Rahmato. In Legalising Land Rights: Local Practices, State Responses and Tenure Security in Africa, Asia and Latin America; Ubink, J.M., Hoekema, A.J., Assies, W.J., Eds.; Leiden University Press: Leiden, The Netherlands, 2009; pp. 59-96.

39. Metaferia, G. Ethiopia and the United States: History, Diplomacy, and Analysis; Algora Pub: New York, NY, USA, 2009.

40. Petras, J.F.; Morley, M.H. The Ethiopian Military State and Soviet-US Involvement in the Horn of Africa. Rev. Afr. Polit. Econ. 1984, 30, 21-31. [CrossRef]

41. Kebbede, G. State capitalism and development: The case of Ethiopia. J. Dev. Areas 1987, 22.

42. Guariso, G.; Whittington, D. Implications of Ethiopian water development for Egypt and Sudan. Int. J. Water Resour. Dev. 1987, 3, 105-114. [CrossRef]

43. Henze, P.B. Ethiopia, Crisis of a Marxist Economy. Analysis and Text of a Soviet Report; RAND Corporation: Santa Monica, CA, USA, 1989.

44. WCD. Dams and Development: A New Framework for Decision-Making the Report of the World Commission on Dams; Earthscan: London, UK, 2000.

45. Verhoeven, $\mathrm{H}$. The politics of African energy development: Ethiopia's hydro-agricultural state-building strategy and clashing paradigms of water security. Philos. Trans. R. Soc. A Math. Phys. Eng. Sci. 2013, 371, 20120411. [CrossRef]

46. Hailu Woldegebrael, E. The Materialization of "Developmental State" in Ethiopia: Insights from the Gibe III Hydroelectric Development Project Regime, Omo Valley. Espacepolitique 2018, 35. [CrossRef]

47. FDRE. Growth and Transformation Plan II (GTP II) (2015/16-2019/20); Main Text; FDRE: Addis Ababa, Ethiopia, 2016; Volume I.

48. Clapham, C. The Ethiopian developmental state. Third World Q. 2018, 39, 1151-1165. [CrossRef]

49. Legese, G.; van Assche, K.; Stellmacher, T.; Tekleworld, H.; Kelboro, G. Land for food or power? Risk governance of dams and family farms in Southwest Ethiopia. Land Use Policy 2018, 75, 50-59. [CrossRef]

50. Crewett, W.; Korf, B. Ethiopia: Reforming Land Tenure. Rev. Afr. Polit. Econ. 2008, 35, 203-220. [CrossRef]

51. Moreda, T. Large-scale land acquisitions, state authority and indigenous local communities: Insights from Ethiopia. Third World Q. 2017, 38, 698-716. [CrossRef]

52. Donham, D.L. Revolution and Modernity in Maale: Ethiopia, 1974 to 1987. Comp. Stud. Soc. Hist. 1992, 34, 28-57. [CrossRef] 
53. Abbink, J. Dam controversies: Contested governance and developmental discourse on the Ethiopian Omo River dam. Soc. Anthropol. 2012, 20, 125-144. [CrossRef]

54. Moore, D.; Dore, J.; Gyawali, D. The World Commission on Dams + 10. Revisiting the Large Dam Controversy. Water Altern. 2010, 2, 3-13. 